\title{
Evaluasi Kinerja Pengelolaan Keuangan Daerah di Provinsi Sulawesi Tenggara
}

\author{
Deni Herdiyana \\ deni.herdiyana@pknstan.ac.id
}

\author{
Nina Andriana \\ nina.andriana@pknstan.ac.id
}

\begin{abstract}
ABSTRAK
Penelitian ini bertujuan untuk menganalisis dan mengevaluasi kinerja pengelolaan keuangan daerah yang dilakukan oleh Pemda di wilayah Provinsi Sulawesi Tenggara yang mencakup profil daerah provinsi dan kab./kota se-Sulawesi Tenggara, kinerja, tantangan, dan masalah pengelolaan keuangan daerah se-Sulawesi Tenggara, dan kebijakan akselerasi dan pembiayaan pembangunan daerah se-Sulawesi Tenggara. Penelitian dilakukan secara naratif eksploratif dengan pendekatan deskriptif kualitatif dan kuantitatif yang dilakukan melalui pengumpulan dan analisis data. Deskriptif kualitatif dilakukan melalui pendalaman dari literatur peraturan perundang-undangan, sedangkan deskriptif kuantitatif dilakukan melalui pengumpulan data sekunder baik dari data APBD maupun data yang bersumber dari BPS. Hasil penelitian menunjukkan terdapatnya berbagai kelemahan dalam pengelolaan keuangan daerah, khususnya belanja daerah. Oleh karena itu, penulis merekomendasikan kepada pemerintah daerah untuk memperbaiki kualitas belanja, yang terdiri dari penetapan APBD secara tepat waktu dan memfokuskan belanja APBD pada peningkatan pelayanan publik, pengentasan kemiskinan, serta perbaikan kesejahteraan.
\end{abstract}

Keywords : Kinerja pengelolaan keuangan daerah, naratif eksploratif, belanja daerah, kualitas belanja, peningkatan pelayanan publik.

\section{Pendahuluan}

Pemerintah Indonesia telah menetapkan visi dan misi pembangunan nasional melalui Rencana Pembangunan Jangka Panjang Nasional Tahun 2005-2025. Adapun definisi dari pembangunan nasional sesuai dengan UU No. 17 Tahun 2007, adalah untuk mewujudkan Indonesia yang mandiri, maju, adil dan Makmur. Adapun untuk mewujudkan visi tersebut, terdapat salah satu misi dari 8 (delapan) misi yang tercantum pada RPJPN, yaitu mewujudkan pemerataan pembangunan dan berkeadilan dengan meningkatkan pembangunan daerah, mengurangi kesenjangan sosial secara menyeluruh dengan meningkatkan keberpihakan kepada masyarakat, kelompok dan wilayah/daerah yang masih lemah, menanggulangi kemiskinan dan pengangguran secara drastic, menyediakan akses yang sama bagi masyarakat terhadap berbagai pelayanan sosial serta sarana dan prasarana ekonomi, serta menghilangkan diskriminasi dalam berbagai aspek termasuk gender. Dengan demikian, salah satu sasaran untuk pemerataan pembangunan dan berkeadilan adalah dengan meningkatkan pembangunan di daerah kepulauan, salah satunya adalah wilayah Provinsi Sulawesi Tenggara.

Untuk mewujudkan salah satu misi tersebut di atas adalah pemerataan pembangunan dan berkeadilan dengan meningkatkan pembangunan daerah yaitu dengan menerapkan kebijakan Otonomi Daerah dan Desentralisasi Fiskal. Kebijakan tersebut diyakini dapat meningkatkan akselerasi pembangunan di daerah, terutama untuk meningkatkan kualitas pelayanan publik dan kesejahteraan masyarakat.

Berkenaan dengan visi misi sebagaimana tercantum pada UU No. 17 Tahun 2007 serta pelaksanaan Nawacita ketiga, peneliti bermaksud untuk melakukan penelitian mengenai kinerja pemda di wilayah Provinsi 
Sulawesi Tenggara dalam pengelolaan keuangan daerah.

Gambaran umum mengenai kesejahteraan masyarakat Provinsi Sulawesi Tenggara dibandingkan dengan kesejahteraan masyarakat secara nasional dapat dilihat pada pie-chart sebagai berikut:



Gambar 1. Gambaran umum mengenai kesejahteraan masyarakat Provinsi Sulawesi Tenggara Tahun 2016

Tingkat pengangguran Provinsi Sulawesi Tenggara sebesar $3,30 \%$, relatif lebih baik dibandingkan dengan tingkat pengangguran nasional sebesar 5,50\%. Sementara itu, jumlah penduduk miskin di Provinsi Sulawesi Tenggara sebanyak 331,71 ribu jiwa, jauh lebih rendah dibandingkan dengan tingkat nasional sebanyak 26.582,99 ribu jiwa. Hal ini, berbanding terbalik dengan persentase penduduk miskin dimana Provinsi Sulawesi Tenggara sebesar $12,88 \%$, relatif lebih tinggi dibandingkan dengan skala nasional sebesar $10,12 \%$.

PDRB per kapita dan gini rasio Provinsi Sulawesi Tenggara secara keseluruhan relatif lebih buruk dibandingkan dengan skala nasional. Angka PDRB per Kapita Provinsi Sulawesi Tenggara sebesar Rp29,20 juta, jauh lebih rendah dibandingkan dengan tingkat nasional sebesar Rp52,79 juta. Sementara itu, gini rasio Provinsi Sulawesi Tenggara sebesar 0,402, relatif lebih tinggi dibandingkan dengan angka nasional sebesar 0,393.

Hal tersebut dapat disimpulkan bahwa tingkat pengangguran di Provinsi Sulawesi Tenggara lebih baik dibandingkan dengan tingkat pengangguran nasional. Namun demikian, tingkat penduduk miskin dan kesenjangan antar penduduk di Provinsi Sulawesi Tenggara relatif lebih buruk dibandingkan dengan tingkat nasional.
Tujuan dari kajian ini adalah untuk melakukan pengumpulan dan pengolahan data serta analisis data untuk mengevaluasi kinerja pengelolaan keuangan daerah yang dilakukan oleh Pemda di wilayah Provinsi Sulawesi Tenggara yang mencakup Profil Daerah Provinsi dan kab./kota se-Sulawesi Tenggara, Kinerja, Tantangan, dan Masalah Pengelolaan Keuangan Daerah se-Sulawesi Tenggara, dan Kebijakan Akselerasi dan Pembiayaan Pembangunan Daerah se-Sulawesi Tenggara. Adapun manfaat kajian tersebut adalah agar menjadi masukan bagi seluruh pemda di wilayah provinsi Sulawesi Tenggara dan referensi bagi para pengambil kebijakan.

\section{Tinjauan Pustaka}

\section{A. Peran Strategis Kebijakan Fiskal}

Sesuai dengan Pasal 18A ayat (2) UUD 1945, hubungan keuangan, pelayanan umum, serta pemanfaatan sumber daya alam dan sumber daya lainnya antara Pemerintah Pusat dan Pemerintah Daerah diatur dan dilaksanakan secara adil dan selaras berdasarkan Undang-Undang. Hal ini merupakan landasan filosofis dan konstitusional pembentukan UU tentang Perimbangan Keuangan antara Pemerintah Pusat dan Pemerintahan Daerah. UU ini mendukung pendanaan atas penyerahan urusan kepada Pemerintahan Daerah yang diatur dalam Undang-Undang tentang Pemerintahan Daerah. Pendanaan tersebut menganut prinsip money follows function, yang kemudian diubah menjadi money follows program yang mengandung makna bahwa pendanaan mengikuti program yang telah ditetapkan pemerintahan dan menjadi kewajiban dan tanggung jawab masingmasing tingkat pemerintahan.

Perimbangan keuangan mencakup pembagian keuangan antara Pemerintah Pusat dan Pemerintahan Daerah secara proporsional, demokratis, adil, dan transparan yang tetap memperhatikan potensi, kondisi, dan kebutuhan Daerah. Pemerintah pada hakikatnya mengemban tiga fungsi utama yakni fungsi distribusi, fungsi stabilisasi, dan fungsi alokasi. 
B. Peran Strategis APBN sebagai Instrumen Kebijakan Fiskal

APBN merupakan Anggaran Pendapatan dan Belanja Negara yang disusun setiap tahun oleh lembaga eksekutif dengan persetujuan lembaga legislatif dengan berpedoman pada Rencana Kerja Pemerintah serta Kerangka Ekonomi Makro dan Pokok-pokok Kebijakan Fiskal. Selain itu, APBN yang disusun selalu mempertimbangkan kondisi ekonomi, sosial, dan perkembangan domestik serta internasional yang terkini.

Tema dari pokok-pokok kebijakan fiskal di tahun 2018 ini adalah pemantapan pengelolaan fiskal untuk mengakselerasi pertumbuhan yang berkeadilan. Sejalan dengan tema tersebut, kebijakan fiskal TA 2018 yang ditetapkan Pemerintah diarahkan untuk mendukung pertumbuhan ekonomi yang berkelanjutan, penciptaan lapangan kerja, pengentasan kemiskinan, dan pengurangan kesenjangan yang tujuan akhirnya adalah terwujudnya kesejahteraan bagi seluruh masyarakat secara lebih berkeadilan.

C. Peran Strategis Desentralisasi Fiskal dalam Pembangunan Daerah, Pelayanan Publik, dan Kesejahteraan Masyarakat

Khusaini menyatakan bahwa desentralisasi fiskal adalah pelimpahan kewewenangan di bidang penerimaan anggaran atau keuangan yang sebelumnya tersentralisasi, baik secara administrasi maupun pemanfaatannya diatur atau dilakukan oleh pemerintah pusat (Priyono, 2019, 15).

Transfer ke Daerah dan Dana Desa (TKDD) merupakan dana yang diperoleh dari APBN yang dialokasikan sesuai dengan porsinya masing-masing kepada seluruh Pemda baik kabupaten/kota maupun provinsi dalam rangka pelaksanaan desentralisasi fiskal. Implementasi kebijakan anggaran TKDD merupakan instrumen kebijakan desentralisasi fiskal dalam rangka untuk mendanai urusan pemerintahan yang menjadi kewenangan daerah, selain memperhatikan kebutuhan pendanaan untuk mendukung penyelenggaraan pemerintahan dan pembangunan tersebut, juga mempertimbangkan kemampuan keuangan negara, kinerja pelaksanaan dan tujuan yang hendak dicapai dalam setiap tahun anggaran berdasarkan program/kegiatan yang telah ditetapkan sebagai prioritas dalam pembangunan nasional.

Untuk mencapai tujuan dari pelaksanaan desentralisasi fiskal, telah disusun kebijakan umum TKDD untuk TA 2018 yang mencakup sebagai berikut:

1. Memperkuat sinkronisasi perencanaan dan penganggaran TKDD dengan alokasi belanja kementerian/lembaga (K/L);

2. Memperbaiki pengelolaan Dana Transfer Umum (DTU), melalui:

a. Pengalokasian Dana Bagi Hasil (DBH) berdasarkan perubahan kewenangan daerah, penyelesaian kurang/lebih bayar DBH, dan optimalisasi penggunaan DBH;

b. Pengalokasian Dana Alokasi Umum (DAU) yang bersifat dinamis yang dapat disesuaikan dengan perubahan PDN neto pada APBN perubahan;

c. Pemberian afirmasi kepada daerah kepulauan dengan meningkatkan bobot variabel luas wilayah laut hingga $100 \%$ dalam perhitungan alokasi DAU; dan

d. Pengaturan penggunaan minimal 25 persen dari DTU untuk belanja infrastruktur.

3. Memperbaiki pengelolaan Dana Transfer Khusus (DTK), melalui:

a. Pengalokasian dana alokasi khusus (DAK) fisik yang lebih difokuskan pada upaya mengurangi kesenjangan layanan dasar publik antardaerah;

b. Pengalokasian DAK fisik berdasarkan usulan daerah (proposal based) dan prioritas nasional, dengan memperkuat sinergi antarbidang, antarprogram, antardaerah dan antarsumber pendanaan;

c. Pengalokasian DAK nonfisik yang lebih tepat sasaran, guna meningkatkan aksesibilitas masyarakat terhadap layanan dasar publik yang semakin terjangkau; dan

d. Penguatan penyaluran DTK berdasarkan kinerja penyerapan dan capaian output kegiatan.

4. Melakukan reformulasi pengalokasian dana insentif daerah (DID) sebagai instrumen insentif dalam transfer ke daerah dan dana desa melalui peningkatan 
alokasi dan penajaman kriteria pengalokasian DID;

5. Meningkatkan efektivitas pemanfaatan dana otonomi khusus dan dana keistimewaan D.I. Yogyakarta; dan

6. Melakukan reformulasi pengalokasian Dana Desa dengan prinsip pemerataan dan berkeadilan dengan memberikan afirmasi bagi desa di daerah tertinggal, perbatasan dan kepulauan, guna peningkatan kesejahteraan dan pengentasan kemiskinan.

Hal ini sejalan dengan hasil penelitian Priyono (2019) yang menyatakan bahwa terdapat peran desentralisasi terhadap tingkat kesejahteraan masyarakat. Selain itu desentralisasi fiskal dapat memperkuat kemampuan keuangan daerah yang digunakan untuk programprogram pembangunan yang dapat mendukung kesejahteraan masyarakat.

D. Masalah dan Tantangan Perkembangan Ekonomi Global dan Domestik

Berdasarkan Gambar 2 pertumbuhan ekonomi periode 2014-2018, perekonomian Indonesia cenderung membaik secara bertahap dengan pertumbuhan ekonomi ratarata sebesar 5\%, meskipun sempat mengalami penurunan pada tahun 2015 sebesar 4,9\%.

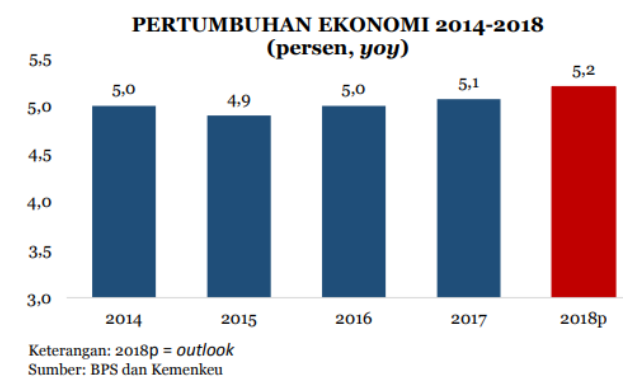

Gambar 2. Pertumbuhan Ekonomi Tahun 20142018

Untuk mendorong pertumbuhan ekonomi, Pemerintah terus meningkatkan kinerja investasi dengan fokus pada pembangunan infrastruktur dan peningkatan iklim investasi di dalam negeri. Untuk peningkatan iklim investasi tersebut, salah satu kegiatan yang dilakukan adalah membangun sistem tunggal perijinan online (Online Single Submission/ OSS). Selain itu, adanya reformasi struktural termasuk di dalamnya reformasi fiskal yang terus dilakukan untuk memperkuat fundamental ekonomi nasional serta menjamin kesinambungan pembangunan, sehingga telah mengembalikan Indonesia ke peringkat layak investasi (investment grade) dari seluruh lembaga rating internasional. Stabilitas ekonomi makro juga terjaga dengan baik sepanjang 2014-2018 meskipun menghadapi tekanan khususnya pada nilai tukar rupiah sebagai imbas dari kebijakan moneter AS.

Sesuai dengan Gambar 3 perkembangan nilai tukar rupiah terhadap dollar AS periode tahun 2014-2018, memasuki tahun 2018 pelemahan nilai tukar rupiah masih berlangsung. Peningkatan risiko yang diakibatkan oleh volatilitas pasar keuangan dunia merupakan faktor utama yang memengaruhi pelemahan nilai tukar rupiah terhadap dolar AS. Selain itu, tekanan eksternal datang dari kebijakan perdagangan AS yang baru di bawah pemerintahan Donald Trump, perang dagang antara AS dengan Tiongkok dan negara lainnya, depresiasi Yuan, rebalancing ekonomi Tiongkok, serta adanya ketidakpastian permasalahan geopolitik. Dari sisi domestik, pelemahan nilai tukar rupiah dipengaruhi oleh meningkatnya kebutuhan pembiayaan impor yang mengalami peningkatan cukup signifikan pada pertengahan pertama tahun 2018, sampai dengan bulan April mengalami kenaikan lebih dari $20 \%$ dibandingkan dengan periode yang sama pada tahun sebelumnya, serta adanya pembayaran utang luar negeri yang jatuh tempo.

Pemerintah sudah semestinya mewaspadai potensi risiko inflasi yang kemungkinan terjadi hingga akhir tahun 2018, seperti meningkatnya harga minyak mentah dunia, volatilitas nilai tukar rupiah terhadap mata



Gambar 3. Perkembangan Rata-rata Nilai Tukar Tahun 2014-2018 
uang asing khususnya Dollar Amerika. Oleh karena itu, perlu kehati-hatian dalam mengambil kebijakan yang dapat mempengaruhi ekspektasi para pelaku pasar dan masyarakat. Selain itu, Pemerintah tetap berhati-hati dalam mengelola risiko administered price yaitu dengan memperhatikan kondisi perekonomian secara global, daya beli masyarakat, serta kesehatan fiskal APBN dan BUMN pelaksana tugas. Dengan mempertimbangkan faktor-faktor tersebut, berbagai upaya telah dilakukan Pemerintah dalam rangka menjaga tingkat inflasi pada level yang rendah dan stabil, sehingga laju inflasi pada tahun 2018 diperkirakan tetap terkendali pada level 3,5\% .

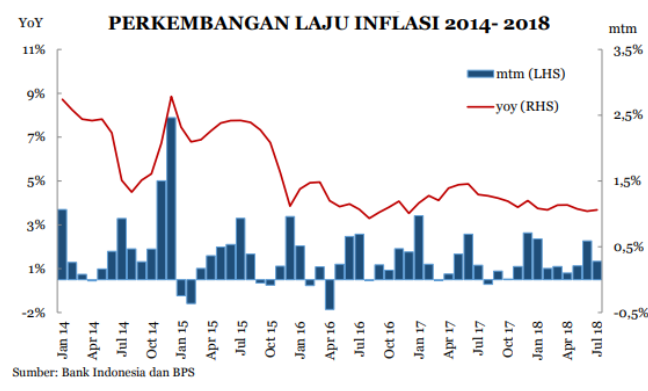

Gambar 4. Perkembangan Laju Inflasi 2014-2018

\section{E. Masalah dan Tantangan yang Dihadapi Dalam Pembangunan Nasional}

Terdapat 2 (dua) tantangan yang dihadapi dalam pembangunan nasional yang bertujuan untuk meningkatkan sarana dan prasarana infrastruktur dan pelayanan publik sehingga nantinya tercapai kesejahteraan masyarakat adil dan merata yaitu adanya tantangan pembangunan nasional dan tantangan ekonomi dalam negeri.

Tantangan pembangunan yang dihadapi diantaranya adalah (1) ketimpangan yang tinggi dalam layanan publik antardaerah, salah satunya terkait akses sanitasi, di Kota Pangkal Pinang 97\% sudah dapat akses sanitasi sedangkan di Kab. Asmat hanya 14\% yang dapat akses sanitasi, (2) penurunan tingkat kemiskinan yang melambat yaitu hanya $10,12 \%$, (3) IPM yang masih rendah yaitu di daerah Papua yang masih 70,79, sehingga masih perlu untuk ditingkatkan, (4) Programme for International Student Assessment (PISA) Score Indonesia termasuk rendah yaitu berada di urutan 62 dari jumlah
69 negara yang disurvei, (5) Tingginya ketimpangan antarkelompok masyarakat dan wilayah, hal ini ditandai dengan indeks Gini yang tinggi sebesar 0,39 , (6) malnutrisi merupakan asupan gizi yang belum memenuhi kebutuhan tubuh yang ideal, sehingga malnutrisi ini masih menjadi masalah serius yaitu sekitar $27,6 \%$.

Adapun tantangan ekonomi dalam negeri yang masih dihadapi adalah rendahnya tingkat inovasi, kapasitas produksi yang terbatas, masih adanya gap yang tinggi antardaerah terkait infrastruktur, teknologi dan tingkat keterampilan SDM yang dimiliki, dan terakhir adalah pasar keuangan yang masih terbatas, serta pemahaman dari masing-masing Pemda yang belum mumpuni terkait pengelolaan alternatif pembiayaan. Sehingga output yang dihasilkan dari permasalahan tersebut adalah rendahnya produktivitas, rendahnya daya saing serta tingginya ketimpangan dan kemiskinan antardaerah. Abidin (2015) mengungkapkan bahwa penggunaan anggaran dana desa masih menemui sejumlah hambatan/permasalahan dalam perencanaan, pelaksanaan, kualitas pelaporan, dan lemahnya kelembagaan desa serta koordinasi dengan pemda kotamadya/kabupaten. Hambatan tersebut perlu diatasi untuk meningkatkan pemerataan pembangunan dan kesejahteraan masyarakat dapat terwujud.

\section{Metode Penelitian}

Penelitian ini merupakan penelitian naratif eksploratif dengan pendekatan deskriptif kualitatif maupun kuantitatif yang dilakukan melalui pengumpulan dan analisis data. Deskriptif kualitatif dilakukan melalui pendalaman dari literatur peraturan perundang-undangan, sedangkan deskriptif kuantitatif dilakukan melalui pengumpulan data sekunder baik dari data APBD maupun data yang bersumber dari BPS. Peneliti melakukan pengumpulan data gambaran perekonomian Provinsi Sulawesi Tenggara dan dibandingkan dengan perekonomian secara nasional, gambaran mengenai kesejahteraan masyarakat Provinsi Sulawesi Tenggara dibandingkan dengan kesejahteraan masyarakat secara nasional, kinerja ekonomi daerah-daerah di wilayah kabupaten/kota/ provinsi Sulawesi Tenggara melalui komposisi nilai dan growth dari PDRB 
(Produk Domestik Regional Bruto) serta tingkat inflasinya, indikator kesejahteraan seProvinsi Sulawesi Tenggara, indikator layanan dasar publik se-Provinsi Sulawesi Tenggara, dan tingkat ketergantungan APBD Provinsi Sulawesi Tenggara terhadap Dana Transfer ke Daerah.

\section{Pembahasan}

\section{A. Kebijakan Akselerasi dan Pembiayaan Pembangunan Daerah se-Sulawesi Tenggara}

1. Tujuan dan Sasaran RPJMN 2015-2019 dan RKP 2018 Khusus Daerah Kepulauan Sesuai dengan Undang-Undang No.17 Tahun 2007 tentang Rencana Pembangunan Jangka Panjang Nasional Tahun 2005-2025, Rencana Pembangunan Jangka Menengah (RPJM) Nasional adalah dokumen perencanaan pembangunan nasional untuk periode 5 (lima) tahunan, yaitu RPJM Nasional I Tahun 2005-2009, RPJM Nasional II Tahun 2010-2014, RPJM Nasional III Tahun 2015-2019, dan RPJM Nasional IV Tahun 2020-2024. RPJM sebagaimana tersebut di atas dijabarkan ke dalam Rencana Kerja Pemerintah (RKP) yang merupakan rencana pembangunan tahunan nasional, yang memuat prioritas pembangunan nasional, rancangan kerangka ekonomi makro yang mencakup gambaran perekonomian secara menyeluruh termasuk arah kebijakan fiskal, serta program kementerian/lembaga, lintas kementerian/lembaga kewilayahan dalam bentuk kerangka regulasi dan pendanaan yang bersifat indikatif.

Tujuan dan sasaran dalam RPJMN Tahun 2015 - 2019 dan RKP Tahun 2018 khusus daerah kepulauan adalah:

\section{RPJMN Tahun 2015 - 2019:}

- Percepatan Pembangunan Kelautan Sebagai negara dengan luas wilayah laut yang sangat besar percepatan pembangunan kelautan merupakan tantangan yang harus diupayakan untuk kesejahteraan seluruh rakyat Indonesia. Dalam kaitan ini penegakan kedaulatan dan yurisdiksi nasional perlu diperkuat sesuai dengan konvensi PBB tentang Hukum Laut yang telah diratifikasi. Disamping itu, tantangan utama lainnya adalah bagaimana mengembangkan industri kelautan, industri perikanan, dan peningkatan pendayagunaan potensi laut dan dasar laut bagi kesejahteraan rakyat Indonesia. Disamping itu upaya menjaga daya dukung dan kelestarian fungsi lingkungan laut juga merupakan tantangan dalam pembangunan kelautan.

- Penyempurnaan dan penguatan peraturan dan kebijakan pembangunan daerah tertinggal, kepulauan dan perbatasan.

Dengan masih adanya kesejangan pembangunan antarwilayah terutama untuk daerah tertinggal, kepulauan, dan perbatasan, maka diperlukan penyempurnaan dan penguatan peraturan dan kebijakan pembaangunan untuk daearah tertinggal, kepulauan dan perbatasan. Dalam buku RPJMN Tahun 2015 - 2019 disebutkan bahwaa masih terdapat 122 kabupaten yang merupakan daerah tertinggal, kawasan perbatasan darat tersebar di lima provinsi dan kawasan perbatasan laut berada di 11 provinsi

- Pengembangan fasilitas pelayanan kesehatan

Dalam rangka meningkatkan kualitas pelayanan kesehataan, perlu didukung dengan fasilitas pelayanan kesehataan yang mencukupi dan memadai. Untuk itu, perlu dilakukan pengembangan fassilitas kesehataan agar masyarakat terlayani kesehatannya dengan baik.

- Perbaikan kesejahteraan dan kualitas hidup masyarakat di perdesaan

Sesuai amanat UU No. 6 Tahun 2014, pembangunan desa ditujukan untuk meningkatkan kesejahteraan dan kualitas hidup masyarakat desa, dengan mendorong pembangunan desa-desa mandiri dan berkelanjutan yang memiliki ketahanan sosial, ekonomi, dan lingkungan. Upaya mengurangi kesenjangan antara desa dan kota dilakukan dengan mempercepat pembangunan desa-desa mandiri serta membangun keterkaitan ekonomi lokal antara desa dan kota melalui pembangunan kawasan perdesaan.

\section{RKP Tahun 2018 Khusus Daaerah Kepulauan \\ - Pengurangan kesenjangan antarwilayah}


Sesuai dengan tema Rencana Kerja Pemerintah (RKP) Tahun 2018, maka pengembangan wilayah ditunjukan pada pertumbuhan dan pemerataan pembangunan. Pertumbuhan pembangunan daerah pada tahun 2018 didorong melalui pertumbuhan peranan sektor jasa, sektor industri pengolahan dan sektor pertanian. Peningkatan kontribusi sektor-sektor tersebut dilakukan seiring dengan terus dikembangkannya kawasankawasan strategis di wilayah yang menjadi main prime mover (pendorong pertumbuhan utama) antara lain Kawasan Ekonomi Khusus, Kawasan Industri, Kawasan Perkotaan (megapolitan dan metropolitan), kawasan pariwisata serta kawasan yang berbasis pertanian dan potensi wilayah seperti agropolitan dan minapolitan.

- Memberikan afirmasi kepada daerah kepulauan dengan menambahkan sub variabel luas wilayah laut dalam variabel luas wilayah pada perhitungan DAU

Bentuk afirmasi ini merupakan salah satu dari arah kebijakan Dana Transfer ke Daerah dan Dana Desa Tahun 2018. Pemberian afirmasi kepada daerah kepulauan ini dilakukan dengan meningkatkan bobot variabel luas wilayah laut hingga 100 persen dalam perhitungan alokasi DAU.

- Mempercepat pembangunan infrastruktur dan pelayanan dasar pada 181 Lokasi Prioritas yang termasuk kategori daerah perbatasan, kepulauan, tertinggal, dan transmigrasi.

Dari sisi pemerataan pembangunan, kebijakan pembangunan daerah diarahkan untuk pengurangan kesenjangan antarwilayah terutama untuk pembangunan kawasan barat dan kawasan timur Indonesia, termasuk wilayah perdesaan, daerah tertinggal dan perbatasan. Kebijakan yang dilakukan adalah dengan mendorong transformasi dan akselerasi pembangunan infrastruktur serta mendorong peningkatan investasi di wilayah Papua, Maluku, Nusa Tenggara, Sulawesi, dan Kalimantan, dan Sumatera; dengan tetap menjaga momentum pembangunan Wilayah Jawa. Mempercepat pembangunan infrastruktur dan pelayanan dasar pada 181 Lokasi Prioritas yang termasuk kategori daerah perbatasan, kepulauan, tertinggal, dan transmigrasi ini dilakukan melalui Dana Alokasi Khusus Afirmasi.

2. Transfer ke Daerah dan Dana Desa Perkembangan Transfer ke Daerah dan Dana Desa di wilayah se Provinsi Sulawesi Tenggara dapat kita lihat pada Gambar 5 dibawah ini.

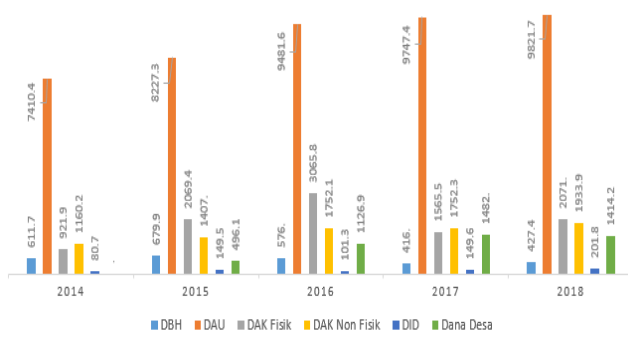

Gambar 5. Perkembangan Transfer ke Daerah dan Dana Desa se Sulawesi Tenggara TA 2014- 2018

Untuk DBH di wilayah se Provinsi Sulawesi Tenggara, pada Tahun 2014 mendapatkan alokasi sebesar Rp611,7 miliar dan pada Tahun 2018 mendapat alokasi sebesar Rp427,4 miliar, sehingga mengalami penurunan sebesar 30,13\%. Untuk DAU di wilayah se Provinsi Sulawesi Tenggara, pada Tahun 2014 mendapatkan alokasi sebesar Rp7.410,4 miliar dan pada Tahun 2018 mendapat alokasi sebesar Rp9.821,7 miliar, sehingga mengalami kenaikan sebesar 32,54\%. Untuk DAK Fisik di wilayah se Provinsi Sulawesi Tenggara, pada Tahun 2014 mendapatkan alokasi sebesar Rp921,9 miliar dan pada Tahun 2018 mendapat alokasi sebesar Rp2.071,0 miliar, sehingga mengalami kenaikan sebesar $125,00 \%$. Untuk DAK Non Fisik di wilayah se Provinsi Sulawesi Tenggara, pada Tahun 2014 mendapatkan alokasi sebesar Rp1.160,2 miliar dan pada Tahun 2018 mendapat alokasi sebesar Rp1.933,9 miliar, sehingga mengalami kenaikan sebesar 66,69\%. Untuk DID di wilayah se Provinsi Sulawesi Tenggara, pada Tahun 2014 mendapatkan alokasi sebesar Rp80,7 miliar dan pada Tahun 2018 mendapat alokasi sebesar Rp201,8 miliar, sehingga mengalami kenaikan sebesar $150,06 \%$. Untuk Dana Desa di wilayah se 
Provinsi Sulawesi Tenggara, pada Tahun 2015 mendapatkan alokasi sebesar Rp496,1 miliar dan pada Tahun 2018 mendapat alokasi sebesar Rp1.414,2 miliar, sehingga mengalami kenaikan sebesar $185,06 \%$. Kebijakan afirmasi TKDD berhasil mendorong kinerja layanan publik di wilayah se- Prov. Sulawesi Tenggara, yang tercermin dari meningkatnya IPM, penyediaan Sanitasi, Air minum, harapan lama sekolah, serta menurunkan tingkat kemiskinan

Kebijakan Afirmasi TKDD di wilayah Sulawesi Tenggara 2018 antara lain:

a. Luas laut Sulawesi Tenggara dihitung $100 \%$ dalam perhitungan DAU;

b. Pengalokasian DAK afirmasi dengan menambah cakupan bidang pendidikan, air, minum, dan sanitasi;

c. Alokasi DAK fisik afirmasi se-Sulawesi Tenggara naik dari Rp40,0 miliar tahun 2017 dan menjadi Rp77,2 miliar tahun 2018;

d. Pemberian tunjangan khusus guru PNSD di daerah terluar, kepulauan dan tertinggal.

3. Anggaran Non Transfer ke Daerah dan Dana Desa

Selain anggaran Transfer ke Daerah dan Dana Desa, terdapat sumber pendapatan lain bagi Daerah dalam membiayai pembangunan daerahnya, antara lain dari Penerimaan Pendapatan Asli Daerah. Selain itu, pembangunan daerah juga mendapatkan alokasi dari Kementerian/Lembaga yang mempunyai lokasi proyek/kegiatan di daerah tersebut. Belanja Kementerian/Lembaga dan Belanja APBD berjalan sinergi sesuai dengan kewenangan masing-masing, agar tidak terjadi tumpang tindih dalam pelaksanaannya.

Di wilayah Provinsi Sulawesi Tenggara, terdapat 4 (empat) Proyek Strategis Nasional dengan nilai lebih dari Rp2,57 triliun yang melibatkan Pemerintah, Swasta, dan BUMN. Pada Tabel 1 di bawah ini dapat dilihat Program apa saja yang termasuk dalam Proyek Strategis Nasional pada wilayah Provinsi Sulawesi Tenggara dalam Tahun 2018.

Tabel 1

Proyek Strategis Nasional

\begin{tabular}{|l|c|c|l|}
\hline \multicolumn{1}{|c|}{ Program } & $\begin{array}{c}\text { Jumlah } \\
\text { (miliar Rupiah) }\end{array}$ & $\begin{array}{l}\text { Jangka } \\
\text { Waktu }\end{array}$ & \multicolumn{1}{c|}{ Lokasi } \\
\hline Bendungan Ladongi & 907 & $2016-2021$ & Kolaka Timur \\
\hline $\begin{array}{l}\text { Bendungan } \\
\text { Pelosika }\end{array}$ & 1.660 & $2018-2019$ & Konawe \\
\hline
\end{tabular}

\begin{tabular}{|l|c|c|l|}
\hline Kawasan Industri & - & - & Konawe \\
\hline $\begin{array}{l}\text { Pembangunan } \\
\text { Smelter }\end{array}$ & - & 2016 & Konawe \\
\hline JUMLAH & $\mathbf{2 . 5 6 7}$ & & \\
\hline
\end{tabular}

4. Pembiayaan

Salah satu isu krusial dalam upaya peningkatan kuantitas dan kualitas pelayanan publik dan kesejahteraan masyarakat adalah penyediaan infrastruktur. Kebutuhan pendanaan infrastruktur dalam RPJMN 20152019 diperkirakan mencapai Rp.4.790 triliun, sementara APBN dan APBD hanya mampu menyediakan sekitar 41\%. Kebutuhan pendanaan infrastruktur dalam RPJMN 20152019 diperkirakan mencapai Rp.4.790 triliun, sementara APBN dan APBD hanya mampu menyediakan sekitar $41 \%$.

Dengan memperhatikan kondisi tersebut, Pemerintah Daerah diharapkan juga dapat melakukan berbagai langkah terobosan dalam mengatasi segala keterbatasan pendanaan untuk pembangunan infrastruktur daerah, terutama melalui perubahan paradigma dalam pengelolaan keuangan daerah yang lebih maju, namun tetap prudent dan terukur. Dengan adanya inovasi tersebut, Pemerintah Daerah telah ikut menciptakan sumber pertumbuhan ekonomi baru yang akan memacu pertumbuhan ekonomi di daerahnya. Saat ini sudah ada beberapa alternatif instrumen pembiayaan daerah, seperti skema Pinjaman Daerah, Obligasi Daerah, Kerjasama Pemerintah dengan Badan Usaha (KPBU), serta Pembiayaan Investasi Non Anggaran (PINA). Selain skema pembiayaan daerah, penyediaan layanan publik dasar juga dapat bersumber dari pendanaan lainnya, yaitu hibah daerah.

Sesuai Peraturan Pemerintah Nomor 30 Tahun 2011 tentang Pinjaman Daerah, Dalam melakukan Pinjaman Daerah, Pemerintah Daerah wajib memenuhi persyaratan sebagai berikut:

a. Jumlah sisa Pinjaman Daerah ditambah jumlah pinjaman yang akan ditarik tidak melebihi 75\% (tujuh puluh lima persen) dari jumlah penerimaan umum APBD tahun sebelumnya;

b. Memenuhi ketentuan rasio kemampuan keuangan daerah untuk mengembalikan pinjaman yang ditetapkan oleh Pemerintah; dan 
c. Persyaratan lainnya yang ditetapkan oleh calon pemberi pinjaman.

Selain memenuhi persyaratan sebagaimana dimaksud pada ayat (1), dalam hal Pinjaman Daerah diajukan kepada Pemerintah, Pemerintah Daerah juga wajib memenuhi persyaratan tidak mempunyai tunggakan atas pengembalian pinjaman yang bersumber dari Pemerintah. Pinjaman Jangka Menengah dan Pinjaman Jangka Panjang wajib mendapatkan persetujuan Dewan Perwakilan Rakyat Daerah.

Dari semua Pemerintah Daerah di wilayah Prov. Sulawesi Tenggara, masih terdapat pemerintah daerah yang tidak memenuhi syarat untuk melakukan pinjaman ke PT. Sarana Multi Infrastruktur yaitu Kab. Buton Tengah, Kab. Buton Selatan, Kab. Konawe Utara, dan Kab. Muna Barat dikarenakan syarat minimal opini BPK atas LKPD 3 tahun terakhir adalah WDP.

\section{B. Tantangan, Masalah, dan Reformasi Pengelolaan Keuangan Daerah se- Sulawesi Tenggara}

1. Pemenuhan Belanja Wajib

Sesuai Peraturan Menteri Dalam Negeri Nomor 33 Tahun 2017 tentang Pedoman Penyusunan APBD TA 2018, telah diatur bagaimana pemerintah daerah menyusun APBD TA 2018 termasuk adanya pemenuhan belanja wajib yang telah diamanatkan dalam peraturan perundang-undangan. Pemenuhan belanja wajib tersebut antara lain adalah dalam rangka peningkatan pelayanan bidang pendidikan, Pemda secara konsisten dan berkesinambungan harus mengalokasikan anggaran fungsi Pendidikan sekurangkurangnya $20 \%$ dari belanja daerah, sesuai amanat dari Pasal 49 ayat (1) Undang-Undang Nomor 20 Tahun 2003 tentang Sistem Pendidikan Nasional.

Pada Tabel 2 di bawah ini dapat dilihat bagaimana pemenuhan belanja wajib dalam APBD TA 2018 untuk daerah se-Sulawesi Tenggara.

Tabel 2

Pemenuhan Belanja Wajib dalam APBD TA 2018 se-Sulawesi Tenggara

\begin{tabular}{|l||l|}
\hline PENDIDIKAN 20\% & $\begin{array}{l}\text { 2 daerah belum memenuhi, yaitu: Kab. } \\
\text { Konawe Utara dan Kab. Konawe Kepulauan } \\
\text { KESEHATAN 10\% }\end{array}$ \\
& $\begin{array}{l}\text { 2 daerah belum memenuhi, yaitu Prov. Sultra } \\
\text { dan Kab. Muna Barat }\end{array}$ \\
\hline
\end{tabular}

\begin{tabular}{|l||l|}
\hline INFRASTRUKTUR & 7 daerah sudah memenuhi, yaitu: Kota \\
25\% DTU & Kendari, Kab. Buton, Kab. Muna, Kab. \\
& Konawe Kepulauan, Kab. Konawe Selatan, \\
& Kab. Muna Barat Kab. Buton Selatan \\
& \\
ALOKASI DANA & (telah memenuhi seluruhnya) \\
DESA 10\% DTU & \\
\hline
\end{tabular}

Dari Tabel 2 tersebut dapat kita lihat bahwa dari keempat kewajiban daerah dalam pemenuhan belanja wajib di atas, untuk pemda di wilayah Sulawesi Tenggara terhadap pemenuhan insfrastruktur $25 \%$ dari Dana Transfer Umum (DTU) adalah yang paling rendah yaitu yang sudah memenuhi hanya 7 daerah (39\% dari total 18 pemda). Selanjutnya, untuk ketaatan pemda yang tertinggi dalam pemenuhan belanja wajib adalah kewajiban menganggarkan Alokasi Dana Desa sebesar $10 \%$ dari DTU, yaitu semua pemda di wilayah Sulawesi Tenggara sudah memenuhi.

Masih adanya daerah yang belum menganggarkan pemenuhan belanja wajib sesuai ketentuan peraturan perundangundangan, mengakibatkan:

- Kinerja layanan publik dan kesejahteraan masyarakat menurun.

- Terhambatnya pembangunan infrastruktur berdampak luas terhadap kinerja perekonomian dan pertumbuhan ekonomi.

- Daerah dapat dikenakan sanksi berupa penundaan penyaluran DAU atas tidak dipenuhinya mandatory spending.

\section{E-Government}

Pada Tahun 2003 telah terbit Instruksi Presiden Nomor 3 Tahun 2003 tentang Kebijakan dan Strategi Nasional Pengembangan E-Government. Instruksi Presiden ini terbit dengan latar belakang adanya tuntutan dari masyarakat agar terbentuknya kepemerintahan yang bersih, transparan, dan mampu menjawab tuntutan perubahan secara efektif. Untuk menjawab tuntutan tersebut, diperlukan penyelenggaraan pemerintahan yang baik dan peningkatan layanan publik yang efektif dan efisien serta adanya kebijakan dan strategi pengembangan e-government. Agar dalam pelaksanaannya terdapat kesamaan pemahaman, keserempakan tindak dan keterpaduan langkah dari seluruh unsur kelembagaan pemerintah. 
Sampai dengan Tahun 2018, masih banyak pemerintah daerah yang belum menerapkan $e$ government dalam pengelolaan keuangan daerah. Secara nasional, penerapan di daerah adalah sebagai berikut:

a. Aplikasi Web Base

- $\quad$ E-Planning baru digunakan di 136 daerah,

- $\quad$ E-Budgeting baru digunakan di 8 Daerah,

- $\quad$ E-Procurement baru digunakan di 536 daerah,

- Aplikasi Penatausahaan baru digunakan di 158 daerah.

b. Aplikasi terintegrasi

Hanya 6 Daerah yang menggunakan aplikasi terintegrasi

c. Aplikasi Dekstop Base

Sebanyak 384 Daerah yang menggunakan aplikasi penatausahaan.

Dalam hal daerah akan menerapkan egovernment, perlu disiapkan langkah-langkah implementasi sebagai berikut:

- Penyusunan dasar hukum e-government (Perkada);

- Pengembangan infrastruktur $e$ government (hardware dan software); dan

- Penyiapan SDM (pelatihan dan bimtek).

3. Standar Biaya

Pengaturan standar biaya yang ada pada Pemerintah Pusat dan Pemerintah Daerah mempunyai dasar hukum sendiri-sendiri. Semua penganggaran atas beban APBN harus mengikuti standar biaya yang diatur dalam Peraran Menteri Keuangan Nomor 71/PMK.02/2013 tentang Pedoman Standar Biaya, Standar Struktur Biaya, dan Indeksasi dalam Penyusunan Rencana Kerja dan Anggaran.

Untuk Pemerintah Daerah, dasar hukum standar biaya yang harus dikuti adalah peraturan kepala daerah yang diterbitkan oleh masing-masing daerah. Tiap daerah polanya berbeda karena ada yang tiap tahun terbit peraturan kepala daerahnya, namun ada juga yang tidak tiap tahun terbitnya. Sampai saat ini, dasar hukum penerbitan Peraturan Kepala Daerah tersebut adalah Pasal 39 ayat (3) Peraturan Pemerintah tentang Pengelolaan Keuangan Daerah. Pasal 39 ayat (3) tersebut berbunyi "Standar satuan harga ditetapkan dengan keputusan kepala daerah". Selanjutnya, Menteri Dalam Negeri melalui Permendagri Nomor 13 Tahun 2006 tentang Pedoman Pengelolaan Keuangan Daerah, telah mengatur dalam Pasal 93 ayat (5) yang berbunyi "Standar Satuan Harga merupakan harga satuan setiap unit barang/jasa yang berlaku di suatu daerah yang ditetapkan dengan keputusan kepala daerah". Diskresi penetapan Standar Satuan Harga menjadi celah terjadinya in-efisiensi anggaran antara lain pada bangunan konstruksi, melalui markup harga satuan dan kolusi dengan kontraktor. Secara nasional, standar biaya yang ada di daerah cenderung lebih tinggi dari standar biaya yang ada di Pemerintah Pusat. Dampak dari standar biaya daerah lebih tinggi dari Pemerintah Pusat adalah terjadi inefisiensi anggaran dan pemborosan, sehingga anggaran untuk program peningkatan kesejahteraan rakyat berkurang.

Begitu pula yang terjadi di beberapa pemerintah daerah di wilayah Sulawesi Tenggara, terdapat penerapan standar biaya yang jauh lebih tinggi dibanding standar biaya masukan yang ada di pemerintah pusat. Uang harian untuk pejabat eselon II di Kab. Konawe Selatan sesuai Peraturan Bupati Konawe Selatan Nomor 41 Tahun 2017 tentang Standar Biaya Masukan Anggaran Pendapatan dan Belanja Daerah Kabupaten Konawe Selatan TA 2018, adalah sebesar Rp2 juta, sedangkan standar biaya di Pemerintah Pusat Rp 530 ribu), sehingga terdapat pemborosan sebesar Rp1,470 ribu. Demikian juga halnya standar biaya pejabat eselon II di Kab. Buton Utara yang pergi ke Jakarta Rp1,6 juta (301,9\% dari standar biaya di Pemerintah Pusat Rp530 ribu), terdapat pemborosan sebesar Rp1.070 ribu (Keputusan Bupati Buton Utara, 2018).

4. Value for Money

Tuntutan baru (transparansi dan akuntabilitas) dalam organisasi sektor publik harus memperhatikan Value for Money dalam menjalankan aktivitasnya. Value for Money merupakan konsep pengelolaan organisasi sektor publik yang mendasarkan pada tiga elemen utama, yaitu ekonomi, efisiensi, dan efektivitas (Mardiasmo, 2009). Berbagai sumber pendanaan pembangunan yang ada perlu dikelola dengan mengutamakan prinsip 
Value for Money, yaitu efisien, efektif, ekonomis, dan produktif. Artinya, keberhasilan pembangunan bukan terletak atau berasal dari besar atau kecilnya dana yang diperoleh, namun bagaimana mengelola dana yang ada seefisien mungkin, agar sekaligus mampu menarik berbagai sumber pendanaan lainnya yang lebih besar, untuk dapat menghasilkan output dan outcome yang maksimal. Value for Money merupakan utilitas yang diperoleh dari setiap rupiah uang yang dibelanjakan baik dengan meminimalkan dana APBD dan menarik sebanyak mungkin investasi swasta maupun menggunakan dana APBD secara efektif dan efisien untuk meningkatkan layanan publik, pengentasan kemiskinan, dan perbaikan kesejahteraan.

Pada Tabel 3 di bawah dapat dilihat perbandingan daerah dengan anggaran belanja yang hampir sama, tapi komposisi dan ouput/outcome berbeda.

Tabel 3

Perbandingan Daerah berdasarkan Value for Money

\begin{tabular}{|c|c|c|c|c|}
\hline DAERAH & $\begin{array}{c}\text { Prov. Sulawesi } \\
\text { Tenggara }\end{array}$ & $\begin{array}{c}\text { Prov. } \\
\text { Kalimantan } \\
\text { Timur }\end{array}$ & $\begin{array}{c}\text { Kab. Konawe } \\
\text { Selatan }\end{array}$ & $\begin{array}{c}\text { Kab. } \\
\text { Labuhanbatu }\end{array}$ \\
\hline REALISASI APBD 2016 & Rp2,66 Triliun & Rp2,56 Triliun Rp798,5 Milyar & Rp800,7 Milyar \\
\hline Belanja Pegawai & $22,24 \%$ & $11,50 \%$ & $40,74 \%$ & $52,55 \%$ \\
\hline Belanja Modal & $28,23 \%$ & $31,19 \%$ & $19,54 \%$ & $23,87 \%$ \\
\hline \multicolumn{5}{|c|}{ OUTPUT/OUTCOME } \\
\hline $\begin{array}{c}\text { Persalinan Ditolong } \\
\text { Tenaga Kesehatan (\%) }\end{array}$ & 86,50 & 92,63 & 67,65 & 100 \\
\hline Akses Air Minum (\%) & 75,82 & 82,69 & 68,94 & 70,13 \\
\hline Penduduk Miskin (\%) & 12,88 & 6,23 & 11,36 & 8,95 \\
\hline Gini Ratio (\%) & 0,40 & 0,30 & 0,38 & 0,31 \\
\hline PDRB per Kapita (Rp juta) & 38,02 & 100,22 & 30,74 & 56,33 \\
\hline
\end{tabular}

Provinsi Sulawesi Tenggara kita bandingkan dengan Provinsi Kalimantan Timur, di mana kedua daerah tersebut mempunyai realisasi anggaran yang hampir sama yaitu untuk Provinsi Sulawesi Tenggara mempunyai realisasi APBD 2016 sebesar Rp2,66 Triliun, sedangkan Provinsi Kalimantan Timur mempunyai realisasi APBD 2016 sebesar Rp2,56 Triliun. Dari realisasi anggaran tersebut, komposisi Belanja pegawai untuk Provinsi Sulawesi Tenggara lebih besar dari Provinsi Kalimantan Timur (22,24\% dibandingkan 11,50\%) dan Belanja Modal untuk Provinsi Sulawesi Tenggara lebih kecil dari Provinsi Kalimantan Timur (28,23\% dibandingkan 31,19\%). Dari Tabel 3 di atas, ternyata untuk daerah yang memiliki Belanja Modal yang lebih besar akan mempunyai Output/Outcome yang lebih baik (untuk
Persalinan ditolong Tenaga Kesehatan, Akses air minum, penduduk miskin, Gini Ratio, dan PDRB per Kapita).

Demikian pula apabila kita lihat perbandingan antara Kab. Konawe Selatan dan Kab. Labuhan Batu yang mempunyai realisasi anggaran 2016 hampir sama (Rp798,5 miliar dibandingkan Rp800,7 miliar), dimana Kab. Konawe Selatan realisasi anggaran untuk Belanja Modal lebih kecil dari Kab. Labuhan Batu (19,54\% dibandingkan 23,87\%). Ternyata, daerah yang realisasi Belanja Modal lebih besar maka Output/Outcomenya akan lebih baik. Pada Tabel 3 dapat kita lihat pula bahwa Output/Outcome untuk Kab. Labuhan Batu lebih baik dari Kab. Konawe Selatan (untuk Persalinan ditolong Tenaga Kesehatan, Akses air minum, penduduk miskin, Gini Ratio, dan PDRB per Kapita).

\section{Kesimpulan dan Saran}

A. Kesimpulan

1. Untuk mewujudkan salah satu misi yang tercantum pada RPJPN yaitu pemerataan pembangunan dan berkeadilan dengan meningkatkan pembangunan daerah, dilakukan dengan menerapkan kebijakan Otonomi Daerah dan Desentralisasi Fiskal. Kebijakan tersebut diyakini dapat meningkatkan akselerasi pembangunan di daerah, terutama untuk meningkatkan kualitas pelayanan publik dan kesejahteraan masyarakat,

2. Pembangunan daerah, termasuk daerah kepulauan, merupakan bagian dari pembangunan nasional memiliki arti penting dan bernilai strategis. Demikian pula halnya dengan Provinsi Sulawesi Tenggara yang merupakan salah satu daerah kepulauan di Indonesia.

3. Transfer ke Daerah dan Dana Desa (TKDD) merupakan dana yang diperoleh dari APBN yang dialokasikan sesuai dengan porsinya masing-masing kepada seluruh Pemda baik kabupaten/kota maupun provinsi dalam rangka pelaksanaan desentralisasi fiskal. Implementasi kebijakan anggaran TKDD merupakan instrumen kebijakan desentralisasi fiskal dalam rangka untuk mendanai urusan pemerintahan yang menjadi kewenangan daerah, selain memperhatikan kebutuhan pendanaan 
untuk mendukung penyelenggaraan pemerintahan dan pembangunan tersebut, juga mempertimbangkan kemampuan keuangan negara, kinerja pelaksanaan dan tujuan yang hendak dicapai dalam setiap tahun anggaran berdasarkan program/kegiatan yang telah ditetapkan sebagai prioritas dalam pembangunan nasional.

4. Gambaran umum tahun 2017 mengenai perekonomian Provinsi Sulawesi Tenggara dibandingkan dengan perekonomian secara nasional adalah sebagai berikut:

- PDRB Provinsi Sulawesi Tenggara sebesar Rp96,98 triliun, sedangkan PDRB secara nasional sebesar Rp13.824,9 triliun, sehingga kontribusi PDRB Provinsi Sulawesi Tenggara terhadap agregasi PDRB se-Indonesia sebesar $0,70 \%$.

- Pertumbuhan ekonomi Provinsi Sulawesi Tenggara sebesar 6,81\%, lebih tinggi dari pertumbuhan ekonomi secara nasional yang hanya $5,07 \%$.

- Sedangkan untuk inflasi dengan tahun dasar 2010, inflasi di Provinsi Sulawesi Tenggara sebesar $3,75 \%$, lebih tinggi dari tingkat inflasi secara nasional sebesar 3,61\%. Hal ini perlu adanya perhatian khusus untuk mencegah efek negative dari tingginya inflasi terhadap pertumbuhan ekonomi Provinsi Sulawesi Tenggara yang positif.

5. Provinsi Sulawesi Tenggara memiliki potensi pembangunan yang besar, khususnya sektor pertanian, perhutanan, perikanan, peternakan dan pertambangan yang dapat dieksplorasi dan dikelola untuk meningkatkan kesejahteraan masyarakat.

6. Capaian Indikator kinerja keuangan daerah, ekonomi (PDRB), pelayanan publik (sanitasi layak, persalinan oleh Tenaga Kesehatan, akses air minum layak, imunisasi), dan kesejahteraan (IPM, penduduk miskin, tingkat pengangguran) di Pemerintah Daerah dalam wilayah Sulawesi Tenggara masih belum merata.

B. Rekomendasi

1. Upaya pembangunan di daerah kepulauan perlu didukung dengan kemudahan interkonektivitas dan ketersediaan infrastruktur. Selain, dana Transfer ke Daerah dan Dana Desa, serta belanja K/L di daerah, Pimpinan daerah dapat menjajaki berbagai alternatif sumber pembiayaan untuk akselerasi pembangunan infrastruktur, penyediaan pelayanan publik, dan kesejahteraan.

2. Pengelolaan pembiayaan harus dilakukan secara efisien, efektif, produktif, dan optimal secara transparan dan akuntabel. Keberhasilan pembangunan bukan berasal dari besar atau kecilnya dana yang diperoleh, namun bagaimana mengelola dana yang ada dengan tepat dan mengutamakan value for money dan bersih dari korupsi.

3. Proses belajar tidak akan pernah berhenti, Knowledge sharing penting agar Pimpinan daerah dapat belajar dari daerah-daerah yang telah sukses dalam mengelola keuangan daerahnya untuk pembangunan dan kesejahteraan masyarakatnya.

4. Berbagai kelemahan dalam pengelolaan keuangan daerah, khususnya belanja daerah perlu segera diperbaiki pada tahuntahun kedepan, dengan melakukan beberapa langkah strategis oleh daerah untuk memperbaiki kualitas belanja, diantaranya melalui :

a. Penetapan APBD secara tepat waktu, agar pelaksanaan belanja daerah bisa dilakukan secara teratur, dan tidak menumpuk di akhir tahun anggaran.

b. Memfokuskan belanja APBD pada peningkatan pelayanan publik, pengentasan kemiskinan, dan perbaikan kesejahteraan, antara lain dengan:

- meningkatkan belanja publik, terutama belanja modal untuk infrastruktur pelayanan dasar;

- meningkatkan efisiensi belanja pegawai, serta belanja barang dan jasa;

- memenuhi belanja mandatory; serta

- mengalokasikan belanja untuk program/kegiatan secara terbatas agar lebih fokus benar-benar sesuai prioritas, dan tuntas dalam penyelesaian dan pemenuhan kebutuhan masyarakat

c. Penerapan Value for Money dalam pengelolaan APBD, yakni dengan 
mengalokasikan belanja yang efektif, efisien dan ekonomis agar dapat memberikan layanan publik yang berkualitas. Hal ini menunjukkan bahwa besaran dana belum tentu berbanding lurus dengan output dan outcome yang bermanfaat bagi masyarakat. Hanya komitmen pemimpin daerah untuk mengelola keuangan daerah secara efektif, efisien, pro-rakyat, transparan, dan akuntabel yang dapat memperbaiki kuantitas dan kualitas layanan publik dan kesejahteraan masyarakat.

d. Penguatan manajemen kas dan perbaikan pengelolaan aset daerah agar lebih tertib dan produktif.

e. Percepatan penerapan e-government, berupa $e$-planning, e-budgeting, dan $e$ procurement, untuk meningkatkan transparansi dan akuntabilitas. Penerapan e-Government secara terintegrasi dalam pengelolaan keuangan daerah akan membantu pemerintah daerah dalam menyusun perencanaan, pelaksanaan program dan kegiatan, penyerapan anggaran belanja secara efektif, efisien dan akuntabel, serta dapat mencegah penyimpangan anggaran dan korupsi.

\section{DAFTAR PUSTAKA}

Abidin, M. Z. (2015). Tinjauan atas pelaksanaan keuangan desa dalam mendukung kebijakan dana desa. Jurnal Ekonomi dan Kebijakan Publik, 6(1), 61-76.

Mardiasmo. (2009). Akuntansi Sektor Publik. Yogyakarta: CV. Andi Offset.

Priyono, N., Juliprijanto, W., \& Setyawan, S. (2019). STUDI EMPIRIS: PERAN

DESENTRALISASI FISKAL TERHADAP PENINGKATAN KESEJAHTERAAN MASYARAKAT DENGAN

\section{PERTUMBUHAN EKONOMI \\ SEBAGAI VARIABEL \\ INTERVENING PADA \\ KABUPATEN/KOTA DI \\ INDONESIA. Jurnal RAK (Riset \\ Akuntansi Keuangan), 4(2), 13-25.}

Republik Indonesia. Undang-Undang Dasar 1945.

Republik Indonesia. Undang-Undang Nomor 20 Tahun 2003 tentang Sistem Pendidikan Nasional.

Republik Indonesia. Undang-Undang Nomor 17 Tahun 2007 tentang Rencana Pembangunan Jangka Panjang Nasional Tahun 2005- 2025.

Republik Indonesia. Peraturan Pemerintah Nomor 30 Tahun 2011 tentang Pinjaman Daerah.

Republik Indonesia. Peraturan Menteri Dalam Negeri Nomor 33 Tahun 2017 tentang Pedoman Penyusunan APBD TA 2018.

Republik Indonesia. Peraturan Menteri Dalam Negeri Nomor 13 Tahun 2006 tentang Pedoman Pengelolaan Keuangan Daerah.

Republik Indonesia. Peraturan Bupati Konawe Selatan Nomor 41 Tahun 2017 tentang Standar Biaya Masukan Anggaran Pendapatan dan Belanja Daerah Kabupaten Konawe Selatan TA 2018.

Republik Indonesia. Keputusan Bupati Buton Utara Nomor 365 Tahun 2017 tentang Standar Satuan Harga Barang, Jasa, dan Perjalanan Dinas Lingkup Pemerintah Kabupaten Buton Utara TA 2018. 